\title{
高分子電解質溶液の理論 (II)
}

\section{大沢文夫}

\section{2. 高分子イオンの形}

A. 高分子イオンの伸長カ 以下に対イオン凝縮現 象とともに，高分子電解質溶液の特性の要因である，高 分子イオンの形の変化の問題についてのべよう。

よくいわ秃ているように, 鎖狀高分子イオンはそのも っている電離基間のクーロン斥力のために伸びようとす る。この力は單純に考えると, 電離基の数 $n$ が坯すほど 大きくなるであろう。しかしまた，この力は高分子イオ ンが対イオンを多く凝縮するほど小さくなる。それは, 高分子イオンの伸縮につれて, それに凝縮している対イ オンの雲も仲縮し, 結局高分子と凝縮対イオンとは, 一 体となって行動し，クーロン厉力に利くのは電離基全部 ではなくて, 凝縮対イオンによって打ち消された残り,す なわち有効電荷 $n^{*}$ であるからである。そして前回のべ たのと同じ近似的見方をすれば， $n^{*}$ をるつ本均牛径 $a$ の系まりのエネルギーは $1 / 2 \cdot n^{* 2} e_{0}^{2} / D a$ とかけるから, そのクーロン质力による伸長力 (体積膨脹の圧力) $P_{1}$ は

$$
\begin{aligned}
& P_{1} / k T=1 / 2 \cdot n^{* 2} e_{0}{ }^{2} / D k T a^{2} \cdot(\partial a / \partial v) \\
& =1 / 6 n^{* 2} e_{0} 2 / D k T \cdot a \cdot 1 / v
\end{aligned}
$$

で與えられる。

こころで高分子イオンの体積 $v$ 中にあるいは $v$ の表面 に凝縮された対イオンの多く注前にものべたように，高 分子イオンのつくるポテンシャルの盆地の中を, ある程 度自由に動いている ( $\Psi$ 結合)。だからこれらの対イオ ンは自らの自由に動きうる空間老增すために, いいかえ れば，運動のエントロピーを霄そうとして，v を大きく しょうとする力の原因となる。この力 $\left(P_{2}\right.$ とかく) は, 氣体の圧力と, あるいはまた, 溶液の滲透圧亡同じ性質 のものである。高分子イオンに溶媒が吸い达まれ，それを 膨脹させようとするためともいえるわけで，ちょうど各 電離基を分子と考えて, これらを透さない牛透膜で $v$ を 包んだときの㳵透圧に等しい圧力が働くと考えられる。 この力は, 半透膜の両側, すなわち $v$ の内外における, 牛透膜を通過できるイオン，すなわち対イオンおよび附 加塩のあるときは副イオンの濃度の装に, 近似的に比例 するとしてよいであろう。故に

$$
\begin{aligned}
P_{2} / k T= & \left(n_{+}+n_{-}\right) / v- \\
& \left\{2 J+\left(n-n_{+}-n_{-}\right) N\right\} /(V-N v)
\end{aligned}
$$

特に附加塩のないときは

$$
P_{2} / k T=\left(n_{+}+n_{-}\right) / v-n^{*} N /(V-N v)=n(1-g)
$$
となる。 $n_{+}\left(n_{-}\right)$は $v$ 中対（副）イオン数。 $V$ は溶液全 体積, $N$ 高分子イオン全数。 $g=n * / n \cdot V / V-N v$ 以前に のべたように滲透圧係数と見られる。

さて有效電荷 $n^{*}$ は附加塩の濃度增加とともに, また 高分子イオンの濃度增加とともに一方的に減少する故, 第 1 の力 $P_{1}$ もまた, これらの濃度篔加につれて減少し ていく。そして濃度が相当稀薄であっても， $n^{*} / n$ 注小 さく， $P_{1}$ は全電離基が有效であると仮定したときにく らべれば,ずっと小さい力になる。これに対して, 第 2 の力 $P_{2}$ の濃度による变化汇このように簡單なものでは ない。まず無限に稀薄な場合には $v$ の內外いずれもイ オン濃度が極めて小さく，その差である $P_{2}$ は 0 とみ られる。この狀態から出発して, 高分子イオンの濃度を 增していこう。それにつれて，対イオンの濃度がらえ， その一部は凝縮され，v內外に対イオンの濃度差が生じ, $P_{2}$ は次第に大きくなる。ある程度濃くなると，凝縮対 イオンの数法相变らず增加するけれども，高分子イオン が溶液を埋めて, その外の体積が減少するため, 対イオ ンの濃度差としてはかえって減少しはじめ, 邆に糸まり 高分子イオンが全溶液を埋めつくしてしまうほどになれ ば，滲透圧力はなくなってしまう。以上を通観すれば, $P_{2}$ はある中間的な濃度でもっとも大きくなることにな る。このような振舞は，(15) 式から明らかなように, 前 にふれた，㑢透圧係数 $g$ がある䟴度で最小になること と対應する。稀薄な溶液に塩を入れていくときも上と同 樣のことがいえ， $P_{2}$ はまず增加し，次に十分塩類が入 れられれば減少する。

$P_{1}, P_{2}$ は (13)，(14)，(15) から，例えば $n$ をある 值にとって, $N v / V$ すなおち体積濃度の函数として，実 際に計算することができる（第 11 困，第 12 図）。期待 通り， $P_{2}$ は体積濃度 $30 \%$ 50\%で最大になる。この 程度の体積濃度は $\mathrm{gr} / 100 \mathrm{cc}$ でかけば，実はかなり小さ いのである（ものによってらがうけれども例えば $0.01 〜$ $0.05 \mathrm{gr} / 100 \mathrm{cc}$ 位)。

$P_{1}+P_{2}$ が高分子イオンの全伸長力 $P$ である。ここで $P$ の內, エネルギー的な力 $P_{1}$ とエントロピー的な力 $P_{2}$ のいずれが, より重要な役目を演ずるかを調べよう。 

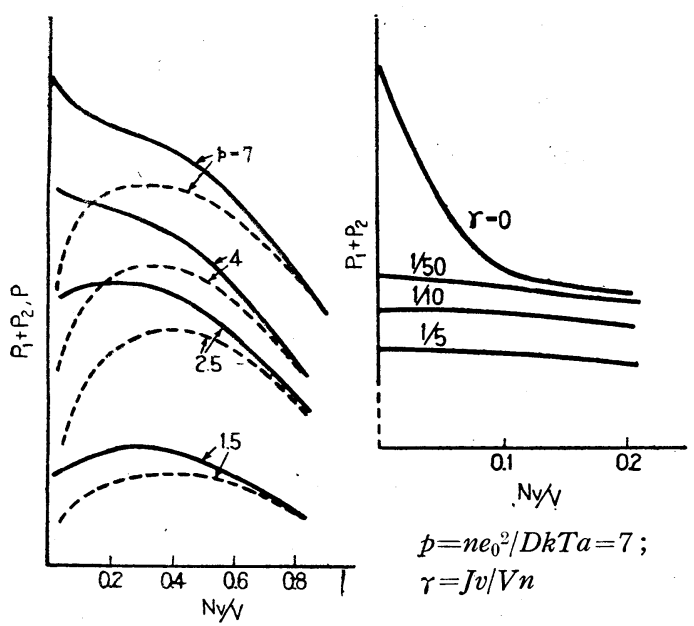

一 : $P_{1}+P_{2}$ (全膨脹力) $; \cdots: P$

(㑢透压力) ; $p=n e_{0}{ }^{2} / D k T a$

第 11 図高分子イオンの膨

脹力とその濃度との関係

（種々の電離基数に䋆いて）

まず附加笽のない場合, 四から高分子濃度が大きいとき はほとんど全く $P_{2}$ のみが働き, 稀薄な領域になっては じめて $P_{1}$ の方が利き, その領域で $P_{2}$ が減少するにも かかわらず全力 $P_{1}+P_{2}$ は大きくなるようになっている ことがわかる。またこの $P_{1}:$ の効果は $n$ が小さい程 $P_{2}$ にくらべて著しく減る。次に高分子イオンの稀薄な場 合, 低分子塩を附加していくと, $n^{*} e_{0}{ }^{2} / D k T a<1$ なら ば, (14), (13), (3) から容易に

$$
P_{1} / P_{2}=1 / 6 \times n^{*} /\left(n-n^{*}\right)
$$

が導かれる。故に塩の涯加によって高分子イオンが対イ オンを凝縮し， その電荷の大部分が中和され， $n^{*} \leqslant n$ と なったときには， $P_{1}$ は $P_{2}$ に比較して無視できるほど 小さい。このような狀態 $n^{*} \ll n$ は普通の高分子イオン では，塩のかなり稀薄な溶液ですでに成立していること は前にのべたところ（第1表参照）である。

結論としては，塩類がほとえど入っていず，かつ高分 子も稀薄な場合を除けば，常に滲透圧力 $P_{2}$ の方が. ク 一ロン斥力 $P_{1}$ よりも大きく寄與することになる。

B. 形の变化高分子イオンはその膨脹力 $P_{1}+P_{2}$ によって膨脹し，伸長する。そして $P_{1}+P_{2}$ が大きいと きほど，てれ汇より伸びた形をとっているであろう。だ から例えば 第 11，12困などは濃度などによる高分子イ オンの形の变化の向きを, 定性的には示しているはずで ある。

本衡狀態で核高分子イオンの膨脹力は, その收絔力 $P_{3}$ と釣り合っている。この收縮力としては, いうまで もなく，鎖狀高分子イオンのミクロブラウン運動による configurational entropy に基づくゴム彈性的な力が考 えられる。これはあまり膨脹あるいは伸長の大きくない 場合には,

$$
P_{3} / k T=1 / v\left(\alpha^{2}-1\right)
$$

とかける。ここに $\boldsymbol{\alpha}$ は同じ高分子イオンがかりに電荷 をもたなかったときにとる大きさを規準にしての伸びの 割合を意味し，この規準狀態の体積を $v_{0}$ とすれば $\alpha^{3}=$ $v / v_{0}$ である。例えばこのような $P_{3}$ を使い, $P_{1}+P_{2}=P_{3}$ から vを解けば，本衡に打ける高分子イオンの大きさ が, 濃度などいろいろの條件の函数として定められる。

計算のもっとも簡單な場合として, 塩類溶液の中に 1 個の高分子をとかしたときを考える。塩が十分濃けれ ば, $P_{1}=P_{2}=0$ である。次第に塩をうすめていくとして, $P_{1}, P_{2}$ を塩濃度 $J / V$ あるいは塩濃度と電離基濃度と の比 $J / V \cdot v / n$ の逆数の幕で展開与るのが便利で, 結果 ほ

$$
\alpha^{5}-\alpha^{3}=1 / 2 \cdot n\left(n / v_{0} \cdot V / J\right)+O\left\{\left(n / v_{0} \cdot V / J\right)^{2}\right\}
$$

它得る。右辺第 1 項は滲透圧力から出たもので, DebyeHückel 近似怙よび Donnan 本衡近似によるものと一 致する。塩類溶液中の高分子イオンの intrinsic viscosity 忐 $\alpha^{3}$ に比例するとすれば，この関係（18）は実驗 的に確めることができる（第 13 図）。結果は定性的には

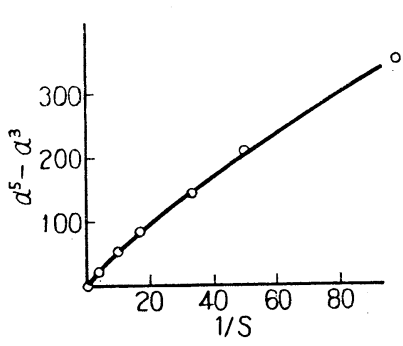

$S^{*}:$ イオン强度 (mol/litre) P.A.A. $+\mathrm{H}_{2} \mathrm{O}+\mathrm{NaCl}$

¿Flory et al: J. Chem.

Phys., 21, 164 (1953)]

第 13 図 高分子イオンの大 きさと附加塩のイオン强 度との関係

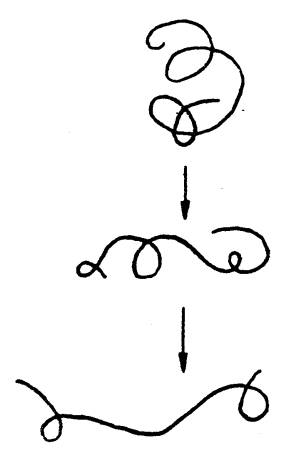

第 14 図 高分子个 オンの形の变化 よい一致が見られた が，定量的には実瞼か らえられた $\alpha^{5}-\alpha^{3}$ の $V / J$ に対する勾配が (18) のそれよりかな り小さい。すなお台計 算結果はあまり伸びす ぎた形を與える。

さて塩類が稀薄にな るにつれて, 高分子イ オンは㣌脹伸長し,つ いには全く伸びきって しまう。この間の形狀 は第 14 図のように, 球狀から. 楕円体狀さらに棒狀へと变化す るであろう。高分子濃度を大き い方かららすめていくときも同 樣である。このような形狀変化 を全般にわたって計算によっ て見易い関係にしてみらびきだ すのは非常に困難である。第 1 にあまり伸びると, 先に $P_{1}$, $P_{2}$ などを求めたときの近似的 な考え方が適用できず, $v, a$ の間を関係づけることもむつか しい。第 2 にこのときは收縮力 $P_{3}$ に対しても (17) のような表式があてはまらない。いわゆる伸びきりの効 果によって $P_{3}$ は (17) よりずっと大きくなると考えら れる。しかし, 定量的な議論にはこのような困難がある 


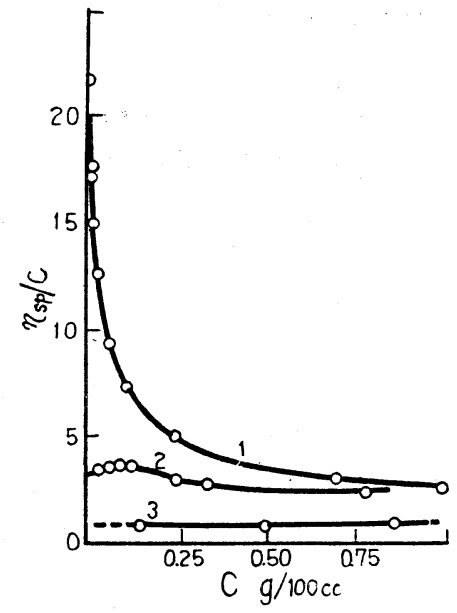

Poly-N-butyl-4-vinyl-pyridonium bromide $+\mathrm{H}_{2} \mathrm{O}+\mathrm{KBr}$

$1: \mathrm{KBr} 0,2: \mathrm{KBr} 0.001 \mathrm{~N}$,

3: $\mathrm{KBr} 0.033 \mathrm{~N}$

¿Fuoss et al: J. Polym. Sci., 3, 246 (1948)]

第 15 図 高分子電解質溶液の粘度
けれども. 定性的 に湔述のように 形狀と濃度との関 係は第 11,12 困な どから想像され， それは多くの実驗 特に粘度の実驗 （第 15 図）から推 定される形狀变化 导，大体江抏いて 說明することがで きよう。

ただ少なくとも 次のような点には 留意しなければな らない。气れはま ず高分子イオンに 凝縮された対イオ ンは十分自由では なく,滲透圧力は (14)であらわされるより小さくである うことである。対イオンの 1 部は電離基と固く結合して おり，それほど固く結合しないまでも，電離基をその近 㳄で中和していると思われる。そうすれば，あまり滲透 圧力は利かない。またかなり伸びた後は一方に長くなれ ば，それと值角方向には細くなる力が强く働き，結局体 積は大きくならず, 滃透圧力は事実上利かなくなってし まう。これらのことが，計算結果がややもす机ば伸びす ぎた形を與える原因であらう。

普通高分子イオンの形はその溶液の粘度から推定する けれども，この結びつけにも大きな問題がある。それは 第 1 に， 1 個の高分子の形とその粘度への奇與との関係 を出すのは高分子が伸びたときには容易でない。第 2 に 高分子イオンが伸びているためもあって，それらの相互 作用が粘度に强く影響するが，その評價がもつかしい。 この相互作用の强いことは例えば $\eta_{s p} / C$ と $C$ の関係に あらわれる Huggins の常数 $k^{\prime}$ が高分子電解質溶液で は著しく大きいことから察せられる。これらは大部分將 來の課題として残されている。光散乱や流動複屈折の測 定から大きさ,形を求めるときにも同樣の障害化当り，い ずれにしても, 高分子イオンの塩類溶液中での intrinsic な狀態を除いては，その狀態を知ることは困難である。

C. 高分子電解質ゲルの伸縮 高分子イオンの澎 脹, 形狀の变化と関連して興味あるのは，いわばマク口 な大きさの高分子イオンであるところの高分子電解質ゲ ルの伸縮の問題である。適当に架橋を與えミことによっ て，3 次元的網狀構造をもたせた鎖狀高分子イオンのゲ ル汇その電離基数の增減にしたがって伸縮する。電離基 数の增減は, 例えば $-\mathrm{COOH}$ 基のときは溶媒にアルカリ
を加え，また徆夋を加えるこ とによって澾せられる。溶 媒の狀態によって伸縮する このようなゲルはいわゆる Mechano-chemical system としで，筋肉のもっと も低次のモデルともみられ ている（第1 6 図)。

周知のように, このよう な一方の荷電をもったマク

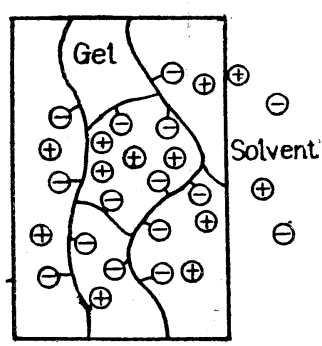

高分子電解質ゲル

第 16 図
口な系は溶媒中では実際上全く中和の狀態にあると考え てよい。イオン篹囲氣的考え方からすれば，ゲルの表面 のイオン雾国氣程度の厚さの部分を除いて內部は完全に 中和されて括り, 有効電何数の全電離基数に対する比: $n * / n$ は無哯できる程小さい。塩類を含まぬ, 電離基の 相手の対イオンのみの溶液でも $n * / n$ が非常に小さいこ とは，例えば (1) 式で $a$ がマクロの order の長さの ときを考えればわかる。このことはいいかえ机ば $n$ は 高分子イオンまたはゲルの体積 $v$ とともに 3 次元的に 增すのに対し， $n^{*}$ は表面積とともに 2 次元的にしか增 さない。だからマクロの系になるほど $n^{*} / n$ は小さい。 そこでこのゲルの膨脹力を高分子イオンのとき同樣滲透 圧力とクーロン斥力とにわけると, 上の事実に対礁して 前者は 3 次元的体積力, 後者は 2 次元的表面力であり, マ クロな系では前者のみを考えれば十分であろう。このこ とは前々節の議論の延長として確めることができる。こ れが認められる以上は, 定量的理論の第 1 段階として Donnan 本衡の理論を應用してよい。そしてゲルの膨脹 力はゲルをつくる電離基を透さない牛透膜で測った，ゲ ルに拉けると同じ濃度の電離基溶液の示す滲透圧に等し い。この考えによって求められた結果は

$$
P_{2} / k T=\left\{(n / v)^{2}+4 C_{0}^{2}\right\}^{1 / 2}-2 C_{0}
$$

である。ここに $C_{0}$ は溶媒のすなわちゲルの外側の塩類 の濃度 (イオン数/cc) である。この膨脹力 $P_{2}$ を, ゲル の網狀構造にもとづくゴム彈性的收縮力（17）と釣り合 わせると, 平衡狀態の体積が定められる。例えばこうし てえられた $n$ と $v$ との関係は実瞼結果をよく說明する ようにみえる(第 17 図)。

外力, 例えば細長いゲルに張力をかけたときの平衡も 同樣に論じられる。膨脹力，收縮力が双方とも上のよう そエントロピー的であり，絕対溫度に比例するのが事実 かどうかは，ゴムにおいてその力がェントロピー的であ ることを確認させたのと同じ実瞼，つまり，長さあるい は体積它一定にしながら，溫度とかけるべき張力との関 係をしらべればわかる。力が全くエントロピー的であれ ば，このとき張力 $K$ は絕対溫度に比例する。高分子電 解質ゲルについて実際にえられた結果は，野口氏の例で は, 


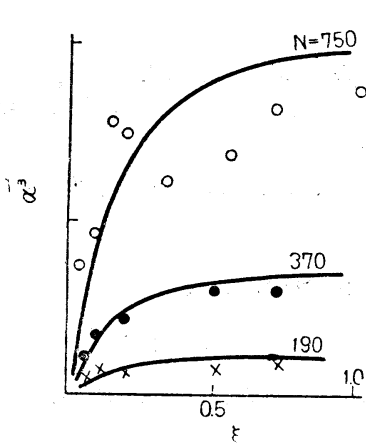

一: 理論曲線； $0,0, \times$ : 実 驗值; $\mathrm{N}$ : Network の 1 本 の鎖の含むセグメントの数

Polymethacrylic acid + divinylbenzene $+\mathrm{H}_{2} \mathrm{O}+\mathrm{NaOH}$ [Katchalsky et al: J. Polym Sci., 7, 571 (1951)

第 17 図 高分子電解質ゲルの そのブラウン運動は制限 膨潤度 $\alpha^{3}$ と中和度 $\xi$ の関係 されている。このことは いかなる影響を拈よ济すであろうか。これには二つの問 題が考えられ, その一つは電離基の偏在の可能性であ る。例えば第 19 困のような構造をもったゲルでは電離 基は鎖に沿った部分に密になり，鎖の間の空間には存在 しない。今簡單のために， 1 價一 1 價の電離基と対イオ

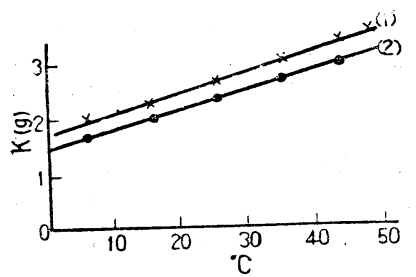

(P.A.A. + P.V.A.) 膜 $+\mathrm{NaOH}$ $+\mathrm{H}_{2} \mathrm{O}$ [野口: 物性論研究 $69(1953)]$

第 18 図 高分子電解質ゲルの 張力と溫度との関係（長さ一 定：(1): $2.89 \mathrm{~cm} ;(2): 2.91 \mathrm{~cm}$

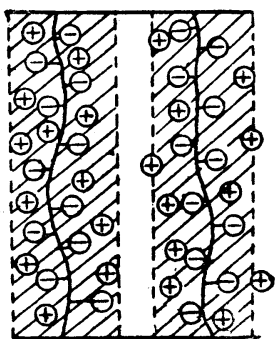

第 19 図 電離基密度 不均一のゲル
ンの系を考えよう。各電離基のまわりには，基の（すな わち対イオンの) 濃度を $M(\mathrm{~mol} / \mathrm{l})$ としたとき， $1 / \kappa=$ $1 / M^{1 / 2} \cdot 8 \AA$ 程度の牛径のイオン雲囲氣が存在している。

一方相隣る基と基との本均距離は，もし基がゲル中に全 く一樣に分布しているとすれば, $1 / M^{1 / 3} \cdot 8 \AA$ 程度にな る。故によほど濃いときを除いて，雲团氣は本均距離よ り大きく，てがいに重り合う。このようなときは各対イ オンはゲル中をすしろ氣体分子的に飛びまわる。ところ が第 19 図のようなゲルでは，本均鎖間距離は，鎖上電 離基間隔を $l \AA$ としたとき，20.1/ $l^{1 / 2} \cdot 1 / M^{1 / 2} \AA \AA$ とな る。だからlが小さければ各鎖のまおりのイオン雾柬氣 は独立となり，多くの対イオンの動く領域は全ゲル中の 限られた領域（図の科線部分）だけになる。こうなれば これら対イオンによる膨脹力は，ゲル全体を電離基溶液 そみたときの洷透压よりずっと小さくなるし，また縱橫
方向によって力が㟟なる。

次に重要なのは電離基が固定されていること自体の影 響である。普通の低分子電解質溶液でも，濃度が濃くな れば，イオン結晶的な秩序が生れてくる。もし固定され た電離基によっててのような秩序の素地ができていれ ば，対イオンの秩序もできやすく，そのため対イオンの エトロピーは減少して滲唀圧效果も弱められるのではな かろらか。そしててのような影響が対イオンが多價のと きには著しくなる可能性がある。これらの問題はもちろ ん高分子イオンの場合にも考えねばならないのである。

以上高分子電解質溶液は鎖狀高分子であるための性質 之電解質である性質を同時㳊って扣り，乙かもそのい ずれとも異なる特性を示すものである。そしてその特性 の本質的な原因は主として高分子イオンによる対イオン 凝縮現象と，高分子イオンの形狀の廣汎な变化とである と考え，この二つの問題を中心亡して論じ，高分子電解 質溶液のいわば物理的な描像をはっきりさせることにつ とめてきた。

しかしな敃重要な問題が残されている。それは第 1 亿 高分子イオンの相互作用の問題であり，これにはゲル 化, コアセルベーションなどの問題も含まれるであろ う。第 2 に非本衡狀態に関係するもの，すなおち，粘 度, 電氣傳導度, 電氣泳動などの理論的考察があり, 特 にこのような性質の研究を通じてイオン凝縮の概念がよ り明確になることが期待される。また第 3 には両性高分 子電解質溶液の問題があり, 蛋白質溶液もその 1 種とし てみるとき，生物学的問題につながるものである。これ らの問題についてはまだ部分的な研究がなされはじめた ばかりであって，大部分將來の課題之なっている。ここ でこれらの現況をくわしく展望して，この分野の理論の これからの方向を考えてみる余裕がないのは残念であ る。

この稿は筆者の理解のすじ道に沿ってかかれたもので あるため，非常に偏ったものになったことを抽びした い。またここにのべたのと異なった考え方をもつ人々も 多いかもしれない。

最後に，著者が高分子電解質について常に有监な御敎 示学賜っている，イオン固定（凝縮）現象をはじめて指 摘された香川繁美敎授に深く感謝したい。

\section{文献}

1) Katchalsky Künzle and Kuhn: J. Polym. Sci., 5, 283 (1950) ; 理論, 完全電離

2) Katchalsky and Lifson: J. Polym. Sci., 13, 43 (1954) ; 11, 409 (1953) ; 理論 (D. H. 的)

3) Hermans and Overbeek: Rev. trav. Chem., 67, 761 (1948) 等; 理論 (D. H. 的)

4) Kimball, Cutler and Samelson: J. Phys. Chem., 56, 57 (1952); 理論 (Donnan 的)

5) Flory: J. Chem. Phys., 21, 162 (1953); 理論 (Donnan 的) (次ぺージ下段へつづく) 


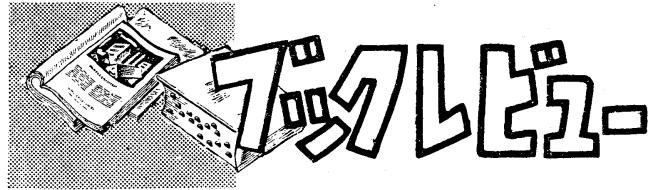

新しい繊维機械（日刊工業講座第1 怣)

荒非溪吉編

(A 5 版, 216 ページ，450 円， 1954 年 6 月, 日刊工業新聞社)

荒井氏の総論の他に, ビスコース速続製造裝置 (堀尾, 高浜両氏), コーホン式連続紡系機 (小川氏), 連続アルカ リセルローズ製造裝置(井口氏), パーフェクト・リング精 紡機（井上氏), 高圧連続繊維加工裝置 (矢沢, 小島両 氏), らせえ熱交換器 (ユンカー, 山本両氏), カラー・・ ストロボ回轉測定裝犆（石川氏), 射出成型機（加治, 椎 名氏), 押出成型機 (山口氏), コアースピンニングフレー ム (桑原氏), 特許 $\mathrm{OM}$ 式スーパーハイドラフト精紡機 (本田氏), 連続樹脂加工機械（中口氏）が收められてい る。私はこの本を一梳して実は三歎した。最近の繊維工 業について知りたいと思っていたことが装点をとらえて 書いてあり,一学にして私は「もの知り」になったからで ある。さすがに荒井さんが編集されただけのことがある とつくづく思った。戰後に日本の紡糸, 紡績がどう变ろ うとしているかはもちろんだが，ポリ塩化ビニルの押し 出しによる系の製造まで出ているのである。私は学校の 講義のタネ本に大いに活用するつもりでいる。そういう わけで私は会う人ごとに大いにこの本を推賞した。「荒 井さんの本を読えだかね，新しいことは何でも書いてあ るぞ。連続紡系でも樹脂加工でもへッチャラさ」というわ けである。しかし世の中にはへそ曲り，トゥへンボクも いるとみ元る。私の机の上から，箱入り，クロース裝の 美しいこの本をとりあげて，じろじろ見ていたすえに， 「君の呚科書にはなるね。しかし工場の技術屋の役には たつか称」といった紳士がいた。私はこの紳士は思かで あると思う。この本はとういう本ではない。序に荒井さ えが美事なパースペクチーブを與えられたが，織維工業 全体の進步を機械裝监の点から見通したもの殅のだ。精 紡工場にいる人はその專門に関する限りこの本から敎え られるところのものは少ないかも知れない（いや，ちょ っとはあるかもしれない)。その代り塩ビの太系の製造 法のことはご存知なからう。纎維屋さえが纎維について 見通しを梁くもっていることはすばらしいにきまってい る。第一にこれほど信用のできる第一流の筆者がそろ元 られた本も少ないではないか。そういう本をよえで自分 の專門に巾をつけ，將來の勉强の基焚とするととは結局 は自分の專門をのばすことなのだ。私は今でもやっばり
纎維屋さん全体に扮く面もなく推賞してまわるつもりで ある。しかし大学の学生諸君には卒業するまで, そっと かくしておいてもいいと考元ている。あんまり敎師のタ ネ本を公開しない方がいいかもしれないではないか。

（大阪市大理工学部敉授 井本稔）

\section{Fibres from Synthetic Polymers}

\author{
R. Hill 編
}

(554 ページ, 1953 年, Elsevier Publishing Co.,)

合成高分子からの繊維について，繊維形成能を有する 各種高分子の合成からはじまって, その構造, 紡絲法打 よび纎維の性能，應用に到るまで，よくま之まって編集 されているのがこの本である。これだけの本はもちろん 一人の著書でよく書き得る本で法なく（書評も乥の通り だと思うが), 英或を主とし, 米, 独も加えた，その道に おける権威者多数の協力によってでき上った本であっ て，そ礼だけに一㤫信用の㧍ける，見ごたえのあるもの である。合成に関する部分它読んで見ても，手際よく， 親切に記述してあり，合成化学者にはこれだけでもまず 一読にあたいすると思う。重合反應，重縮合反㣹につい ての物理化学的考察とともに繊維形成能を有するビニル 柔重合物の製法抢よびポリアミド，ポリエステル，ポリ ウレタンの諘法については充実した解說があり, 外にポ リエーテル，ポリスルホン，ポリ尿素，ポリチオ尿素， ポリヒドラジド, ポリアミノトリアゾール, ポリペプチ ドの合成など有機化学者が見て参考になる紹介も多い。 上記のような合成関係の記述が7龺までであって, 第 8 量 から 12 章までは高分子の構造と性質の関連について基 礎的な知識が一貫して述べられている。すなわち第 8 章 では分子量と分子量分配について, 第 9 章から 12 章まで は同じ著者 (Bunn) によって分子構造之纎維形成能 (特 に結晶性）との関連, 結晶化, 結晶化度, 配列度, 結晶 構造, 融点, 二次轉移点等についてその測定法分子構造 との関係, 繊維形成上の意義について詳細に述べられて いる。このBunnにより書かれた約 100 頁は本書の中 でも最も充実した部分といえよう。第 13 卓においては, 濕式乾式紡系の最も重要な過程である溶解についてその 基礎理論から溶解性と分子構造, さらにゲル化の問題に 言及している。第 14 啅から 16 章までは熔融, 濕式乾式 の紡系法についてそれぞれ專門家によって実際的見地か ら述べられている。要するに本書はその序文に述べられ ているごとく理論的基檚に重点を抄き可能な限りに打い て実際的な結果と結びつけようという努为が美事に結実 乙, 初心者にも專門家にも興味をもって読める良書であ る。またどの章も各々独立しどこからでも読めるのが読 者にとっては便利な点であろう。

（東京工業大学 岩倉義男・植松市太郎）
6) Osawa, Imai and Kagawa: J. Polym. Sci., 13, 93 (1954); 理論

7) Fuoss, Katchalsky and Lifson: Proc. Natl. Acad. Sci., 37, 579 (1951) ; 理論（棒)

8) 今井 (大沢)：物性論研究, $52,59,62$ 等; 理論 (イ オン凝縮)

9) Hill : J. Che\%n. Phys., 20, 1259 (1952); 理論 (ゲ ル)
10) Asakura, Imai and Osawa: J. Polym. Sci., 13, 499 (1954); 理論 (ゲル)

その他理論に関しても多くの文献あり, 実驗をも含め れば莫大な数の文献があると思われるが，それに関して は, もっとも新しい綜合的報告と思われる。

Katchalsky : J. Polym. Sci., 12, (1954) Symposium on Macromolecules : p. 159〜184 の最後の表を見られ たい。 